Article

\title{
Metronidazole and Secnidazole Carbamates: Synthesis, Antiprotozoal Activity, and Molecular Dynamics Studies
}

\author{
Genaro Rocha-Garduño ${ }^{1}$, Norma Angélica Hernández-Martínez ${ }^{1}$, Blanca Colín-Lozano ${ }^{1}$, \\ Samuel Estrada-Soto ${ }^{1}{ }^{(\mathbb{D}}$, Emanuel Hernández-Núñez ${ }^{2}{ }^{\circledR}$, Fernando Daniel Prieto-Martínez ${ }^{3}{ }^{(1)}$, \\ José L. Medina-Franco $^{3}{ }^{(\mathbb{C}}$, Juan Bautista Chale-Dzul ${ }^{4}{ }^{(0}$, Rosa Moo-Puc $\left.{ }^{5}{ }^{(}\right)$and \\ Gabriel Navarrete-Vázquez ${ }^{1, *(1)}$
}

1 Facultad de Farmacia, Universidad Autónoma del Estado de Morelos, Cuernavaca, Morelos 62209, Mexico; azrg90@gmail.com (G.R.-G.); norma.hernandezm@uaem.edu.mx (N.A.H.-M.); clbi_ff@uaem.mx (B.C.-L.); enoch@uaem.mx (S.E.-S.)

2 Cátedra CONACyT, Departamento de Recursos del Mar, Centro de Investigación y de Estudios Avanzados del IPN, Unidad Mérida, Yucatán 97310, Mexico; emanuel.hernandez@cinvestav.mx

3 Facultad de Química, Departamento de Farmacia, Universidad Nacional Autónoma de México, México City 04510, Mexico; ferdpm4@hotmail.com (F.D.P.-M.); medinajl@unam.mx (J.L.M.-F.)

4 Laboratorio de Apoyo a la Vigilancia Epidemiológica, Hospital de Especialidades 1, Centro Médico Nacional Ignacio García Téllez, Instituto Mexicano del Seguro Social, Mérida 97150, Yucatán, Mexico; jchaledzul@gmail.com

5 Unidad de Investigación Médica Yucatán, Unidad Médica de Alta Especialidad, Centro Médico Nacional Ignacio García Téllez, Instituto Mexicano del Seguro Social, Mérida 97000, Yucatán, Mexico; moopuc@gmail.com

* Correspondence: gabriel_navarrete@uaem.mx; Tel.: +52-777-329-7089

Received: 23 January 2020; Accepted: 11 February 2020; Published: 12 February 2020

\begin{abstract}
We prepared a series of 10 carbamates derivatives based on two common antiprotozoal drugs: metronidazole (1-5) and secnidazole (6-10). The compounds were tested in vitro against a set of two amitochondriate protozoa: Giardia duodenalis and Trichomonas vaginalis. Compounds 1-10 showed strong antiprotozoal activities, with potency values in the low micromolar-to-nanomolar range, being more active than their parent drugs. Metronidazole carbamate (1) was the most active of the series, with nanomolar activities against $G$. duodenalis $\left(\mathrm{IC}_{50}=460 \mathrm{nM}\right)$ and $T$. vaginalis $\left(\mathrm{IC}_{50}=\right.$ $60 \mathrm{nM}$ ). The potency of compound $\mathbf{1}$ was 10 times greater than that of metronidazole against both parasites. None of compounds showed in vitro cytotoxicity against VERO cells tested at $100 \mu \mathrm{M}$. Molecular dynamics of compounds 1-10, secnidazole, and metronidazole onto the ligand binding site of pyruvate-ferredoxin oxidoreductase of T. vaginalis and the modeled $\beta$-tubulin of $G$. duodenalis revealed putative molecular interactions with key residues in the binding site of both proteins implicated in the mode of action of the parent drugs.
\end{abstract}

Keywords: carbamates; metronidazole; molecular dynamics; parasites; secnidazole

\section{Introduction}

Giardia duodenalis is an intestinal parasite that infects several mammalian hosts including humans, and it is considered a leading cause of waterborne diarrheal disease and malabsorption syndrome [1]. Trichomonas vaginalis is the etiologic agent of the most common non-viral sexually transmitted disease in humans [2]. The chemotherapy against giardiasis and trichomoniasis is based on the use of 5-nitroimidazole drugs [3], such as metronidazole and secnidazole (Figure 1). 


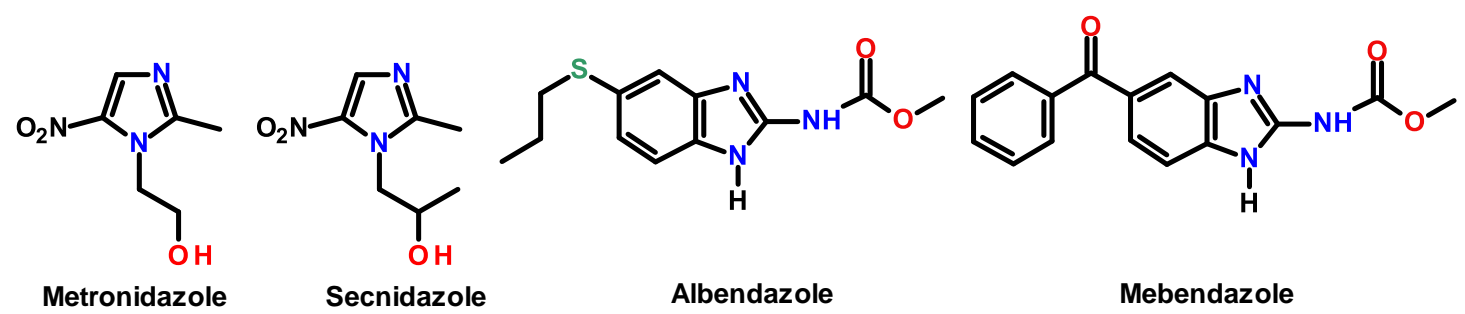

Figure 1. Most common antiprotozoal 5-nitroimidazole and benzimidazole methylcarbamate drugs of choice.

Metronidazole and secnidazole are prodrugs that are reductively activated (the nitro group is reduced) under low oxygen tension to produce free radical intermediates that form adducts with numerous biomolecules such as nucleic acids, proteins, and membrane lipids [4]. However, the clinical resistance to this chemotherapy reveals the need to search for novel and improved antiprotozoal drugs $[4,5]$. The mode of action of 5-nitroimidazoles is multifactorial [6], but one of the most accepted mechanisms is inhibition of the pyruvate-ferredoxin oxidoreductase (PFOR) [7]. Several benzimidazoles $[8,9]$ and carbamates, such as albendazole and mebendazole, have shown giardicidal effects through the inhibition of $\beta$-tubulin polymerization [10]. In an effort to improve the antiprotozoal activity of this 5-nitroimidazole, we suggest the modification of its alcohol tail by several carbamates, increasing the lipophilicity of compounds and exploring the participation of the carbamate in the activity through the potential inhibition of $\beta$-tubulin polymerization plus the inhibition of PFOR. Thus, the in vitro antiparasitic effects of 10 newly designed carbamates on intestinal protozoa G. duodenalis, urogenital tract protozoa T. vaginalis, the cytotoxicity over mammalian VERO cells, and the molecular docking and dynamics prediction of this mode of binding over PFOR and $\beta$-tubulin are reported in this work.

\section{Results and Discussion}

\subsection{Chemistry}

Compounds 1-10 were synthesized starting from metronidazole (11) and secnidazole (12), which were reacted with appropriated isocyanates 13-17 (Scheme 1). Title compounds were recovered with $51-95 \%$ yields and were purified by recrystallization. In the ${ }^{1} \mathrm{H}$ NMR spectra, we assigned the signals of the respective protons of the carbamate derivatives 1-10 on the basis of their chemical shifts, multiplicities, and coupling constants. All compounds showed a typical single signal ranging from 7.93 to $8.80 \mathrm{ppm}$, attributed to $\mathrm{H} 4$ of the imidazole ring. Another simple signal fluctuating from 2.05 to $2.48 \mathrm{ppm}$ was assigned to the methyl group attached at position two of the imidazole. For the ${ }^{13} \mathrm{C}$ NMR spectra, constant signals were found for the imidazole heterocycle: one signal at 150.1-156.8 ppm, attributed to $C 2$, and two signals at 128.7-138.3 and 138.5-146.1 ppm, assigned to C4 and C5, respectively. Another recurrent signal was found in downfield shifts from 151.1 to $161.1 \mathrm{ppm}$, belonging to the carbamate carbonyl group. The methyl group attached at position 2 of imidazole always appeared at 14.3-19.1 ppm. 

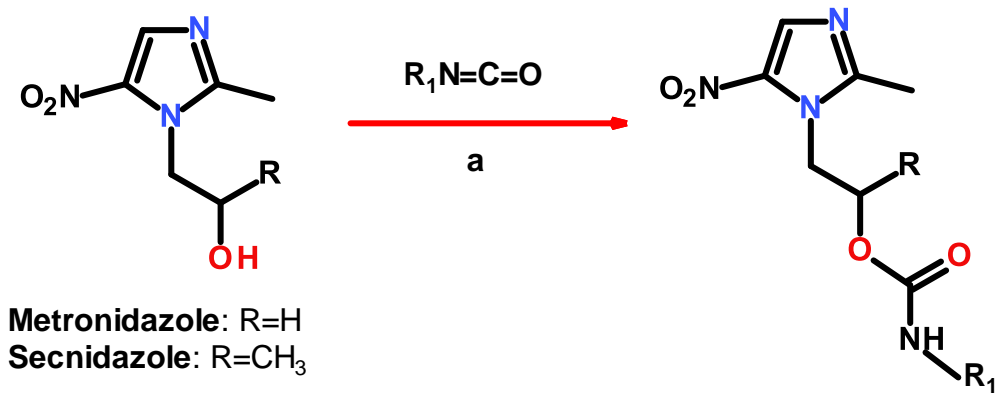

Metronidazole: $\mathrm{R}=\mathrm{H}$ Secnidazole: $\mathrm{R}=\mathrm{CH}_{3}$

\begin{tabular}{|c|c|}
\hline 1: R=H; $\mathrm{R}_{1}=$ Cyclohexyl & 6: $\mathrm{R}=\mathrm{CH}_{3} ; \mathrm{R}_{1}=$ Cyclohexyl \\
\hline 2: $\mathrm{R}=\mathrm{H} ; \mathrm{R}_{1}=$ Phenyl & 7: $\mathrm{R}=\mathrm{CH}_{3} ; \mathrm{R}_{1}=$ Phenyl \\
\hline 3: $\mathrm{R}=\mathrm{H} ; \mathrm{R}_{1}=4$-Chlorophenyl & 8: $\mathrm{R}=\mathrm{CH}_{3} ; \mathrm{R}_{1}=4-$ Chlorophenyl \\
\hline 4: R=H; $\mathrm{R}_{1}=4$-Fluorophenyl & 9: $\mathrm{R}=\mathrm{CH}_{3} ; \mathrm{R}_{1}=4$-Fluorophenyl \\
\hline 5: R=H; $\mathrm{R}_{1}=4$-Nitrophenyl & 10: $\mathrm{R}=\mathrm{CH}_{3} ; \mathrm{R}_{1}=4$-Nitrophenyl \\
\hline
\end{tabular}

Scheme 1. Synthesis of carbamates 1-10: (a) triethylamine, $\mathrm{NH}_{4} \mathrm{Cl}$ (cat.), toluene, reflux.

\subsection{In Vitro Antiprotozoal Activity}

The inhibition of in vitro growth of the amitochondriates Giardia duodenalis and Trichomonas vaginalis by compounds $\mathbf{1} \mathbf{- 1 0}$ is summarized in Table 1 .

Table 1. In vitro antiprotozoal and cytotoxic effects of carbamates 1-10 on Giardia duodenalis and Trichomonas vaginalis.

\begin{tabular}{|c|c|c|c|c|c|c|}
\hline \multirow{2}{*}{ Compound } & \multicolumn{2}{|c|}{$\mathrm{IC}_{50}(\mu \mathrm{M})^{\mathrm{a}}$} & \multirow{2}{*}{$\begin{array}{l}\mathrm{CC}_{50}(\mu \mathrm{M})^{\mathrm{a}} \\
\text { VERO Cells }\end{array}$} & \multicolumn{2}{|c|}{$\mathrm{SI}=\mathrm{CC}_{50} / \mathrm{IC}_{50}$} & \multirow[t]{2}{*}{ MLogP } \\
\hline & G. duodenalis & T. vaginalis & & G. duodenalis & T. vaginalis & \\
\hline 1 & $0.46 \pm 0.01$ & $0.06 \pm 0.01$ & $>100$ & $>217$ & $>1666$ & 3.73 \\
\hline 2 & $0.98 \pm 0.01$ & $0.09 \pm 0.01$ & $>100$ & $>102$ & $>1111$ & 1.72 \\
\hline 3 & $1.14 \pm 0.12$ & $1.79 \pm 0.12$ & $>100$ & $>87$ & $>55$ & 2.4 \\
\hline 4 & $2.03 \pm 0.01$ & $3.22 \pm 0.21$ & $>100$ & $>49$ & $>31$ & 1.89 \\
\hline 5 & $2.43 \pm 0.02$ & $6.25 \pm 0.12$ & $>100$ & $>41$ & $>16$ & 1.68 \\
\hline 6 & $2.64 \pm 0.61$ & $8.64 \pm 0.73$ & $>100$ & $>37$ & $>11$ & 3.87 \\
\hline 7 & $1.67 \pm 0.21$ & $6.52 \pm 0.71$ & $>100$ & $>59$ & $>15$ & 1.86 \\
\hline 8 & $4.05 \pm 0.24$ & $5.93 \pm 0.51$ & $>100$ & $>24$ & $>16$ & 2.54 \\
\hline 9 & $3.23 \pm 0.11$ & $4.82 \pm 1.08$ & $>100$ & $>30$ & $>20$ & 2.02 \\
\hline 10 & $0.86 \pm 0.09$ & $9.99 \pm 0.56$ & $>100$ & $>116$ & $>10$ & 1.82 \\
\hline Metronidazole & $4.42 \pm 0.23$ & $0.93 \pm 0.12$ & $>100$ & $>22$ & $>107$ & -0.47 \\
\hline Secnidazole & $4.11 \pm 0.12$ & $13.45 \pm 1.23$ & $>100$ & $>24$ & $>7$ & -0.10 \\
\hline
\end{tabular}

The biological activity of carbamates 1-10 was compared with the activity of the two parent antiprotozoal drugs of choice: metronidazole and secnidazole (Figure 1), which are commercial drugs used for standard therapies. All the carbamates showed strong giardicidal activity, with potency values oscillating from the low micromolar to the nanomolar range, being more active than or equipotent to their parent drugs. Compound $\mathbf{1}$ (cyclohexylcarbamate of metronidazole) and compounds $\mathbf{2}$ and $\mathbf{1 0}$ (phenylcarbamate of metronidazole and 4-nitrophenylcarbamate of secnidazole, respectively), were the most potent of the series $\left(\mathrm{IC}_{50}\right.$ ranging from 0.46 to $\left.0.96 \mu \mathrm{M}\right)$ against $G$. duodenalis. They were almost 5-10 times more potent than metronidazole and secnidazole, which were equipotent among them. All carbamates were much more lipophilic than metronidazole and secnidazole, with a calculated MlogP around 1.68-3.87. This physicochemical property is important for high permeability of compounds across the protozoal membrane [11]. In our studies of T. vaginalis, compounds $\mathbf{1}$ and $\mathbf{2}$ also exhibited nanomolar trichomonicidal effects ( $\mathrm{IC}_{50}=60$ and $90 \mathrm{nM}$, respectively). They were 10- to 15 -fold more potent than metronidazole, which is the drug of choice for trichomoniasis. Secnidazole was the least potent compound against $T$. vaginalis, but all its carbamate derivatives $\mathbf{6}-\mathbf{1 0}$ were more potent than this 
parent drug. This result is remarkable since if Trichomonas is more resistant to secnidazole treatment, its carbamate derivatives could be a possible therapeutic option for this protozoosis. In summary, the preliminary structure-activity relationship (SAR) analysis revealed that cyclic unsubstituted metronidazole carbamates $\mathbf{1}$ and $\mathbf{2}$ are the most potent compounds against both parasites. Of note, the SAR derived from the results in Table 1 is based on the biological activity measured with the entire parasite and not with isolated molecular targets (see Section 2.3).

\subsection{In Vitro Cytotoxicity Assay}

Compounds 1-10, metronidazole, and secnidazole were evaluated for their intrinsic toxicity against mammalian VERO cell lines (Table 1), showing very low median cytotoxic concentration $\left(\mathrm{CC}_{50}>100 \mu \mathrm{M}\right)$. The selectivity index $(\mathrm{SI})$ is the ratio of cytotoxicity to biological activities. If SI is greater than 10 , it is typically an indicator that the underlying antiprotozoal activity is not due to the intrinsic cytotoxicity of a given compound [12]. Compounds 1-10 showed nanomolar to micromolar giardicidal activities and no observable cytotoxic effects at a $100 \mu \mathrm{M}$ concentration, showing selectivity indexes prominently higher than 20 . This implies that carbamates $\mathbf{1 - 1 0}$ are more selectively toxic against $G$. duodenalis than against mammalian cells. The same parasiticidal discrimination was observed between T. vaginalis and VERO cells.

\subsection{Molecular Docking and Dynamics Studies}

Based on the in vitro antiparasitic assays, the most active compounds (1 and 2) were selected for further computational studies to explore their putative mechanism of action at the molecular level. Molecular modeling studies were performed with two antiprotozoal relevant molecular targets: PFOR and $\beta$-tubulin. These two targets were chosen based on the known relationship with the parent compounds. A preliminary molecular docking simulation was performed to assess the putative binding mode of compounds $\mathbf{1}$ and $\mathbf{2}$ with the proposed targets. Then, molecular dynamics simulations were conducted to determine the relative stability of in silico binding modes. We emphasize that the molecular modeling studies reported in this work are intended to hypothesize the ligand-target interactions with two putative molecular targets. However, we did not intend to provide a detailed explanation for experimental SAR based on the predicted binding models. This is because it is not feasible to establish a reliable correlation between the measured antiprotozoal activity in vitro using the entire parasite, with the binding models derived with isolated 3D coordinates of the putative and isolated molecular targets. In vitro experiments have a significantly larger number of variables that cannot be addressed with in silico studies.

\subsubsection{Docking}

Molecular docking suggested that compounds $\mathbf{1}$ and $\mathbf{2}$ have the potential to internalize in the vicinity of the colchicine binding site [13] of $\beta$-tubulin. In the binding models, both compounds form hydrogen bonds interactions with Gln-245, Ser-352, and form $\pi$-sp ${ }^{3}$ interactions with Leu-246 (Figures 2 and 3). In addition, the predicted binding poses of $\mathbf{1}$ and $\mathbf{2}$ are characterized by several hydrophobic contacts with Cys-239, Phe-242, and Pro-243. Compound 1 showed a polar contact with Ser-238 (Figure 2), which may be due to the higher flexibility of the cyclohexane, facilitating a better fit in the binding cavity for the imidazole ring. 


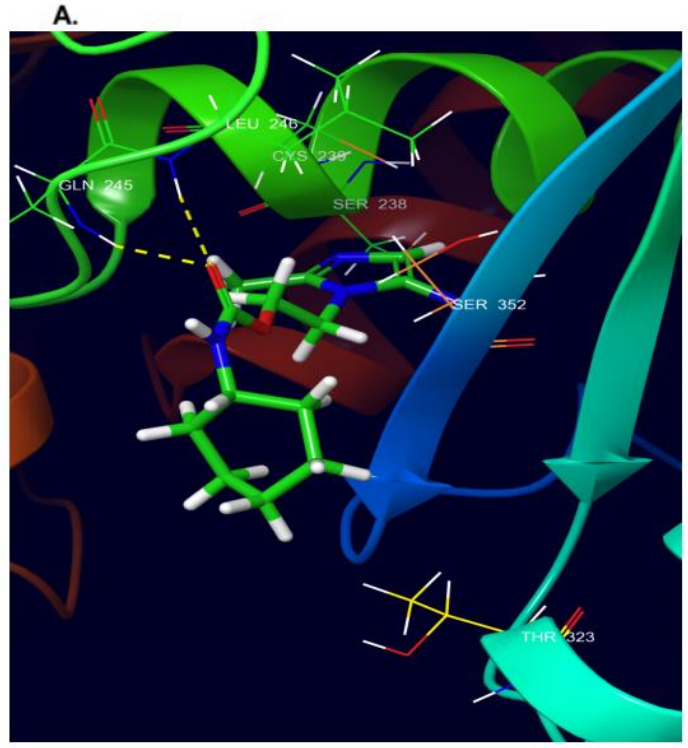

B.

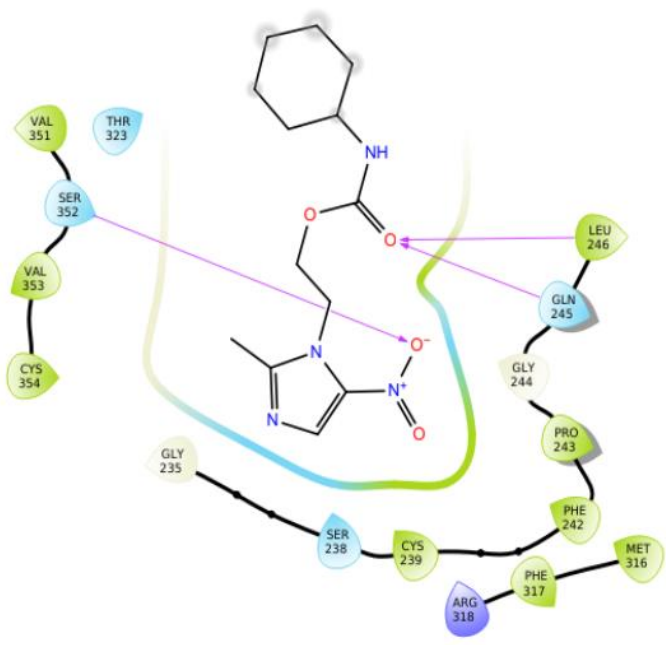

Figure 2. (A) 3D and (B) 2D representation of the binding model of compound 1 in the vicinity of the colchicine binding site of $\beta$-tubulin.

A.

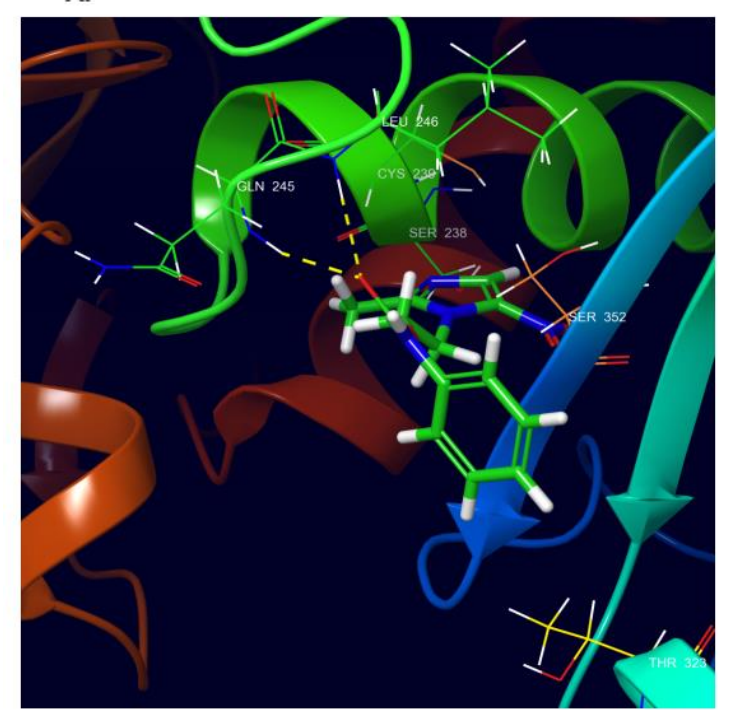

B.

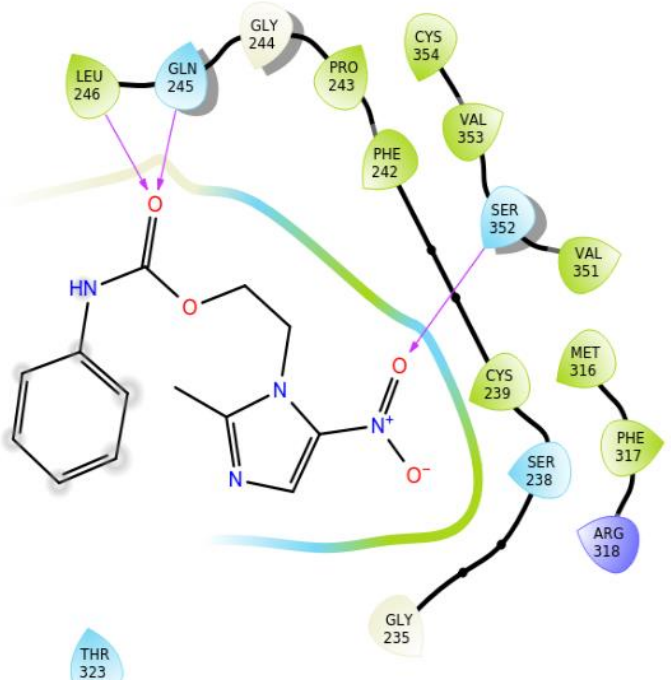

THR
323

Figure 3. (A) 3D and (B) 2D representations of the binding model of compound 2 in the vicinity of colchicine binding site of $\beta$-tubulin.

For PFOR, we studied the previously proposed site for metronidazole [14], around Thr-37, close to the catalytic site. Docking simulations showed that metronidazole and the newly designed compounds have a suitable orientation for the binding site, this is, with the nitro group pointing toward the [2Fe-2S] core. Additionally, the scoring of compounds $\mathbf{1}$ and $\mathbf{2}$ was significantly better than that of metronidazole due to a better fit on the site (see Supplementary Materials). The main protein-ligand contacts of both compounds were with Leu-31, Met-32, Ser-33, Asp-36, Lys-7, and Lys-46 (Figures 4 and 5). Docking poses provide a plausible explanation for the lower activity against $T$. vaginalis of bulky-substituted compounds on the R-position, as the size of the site could prevent the proper orientation of the 5-nitroimidazole scaffold. 
A.

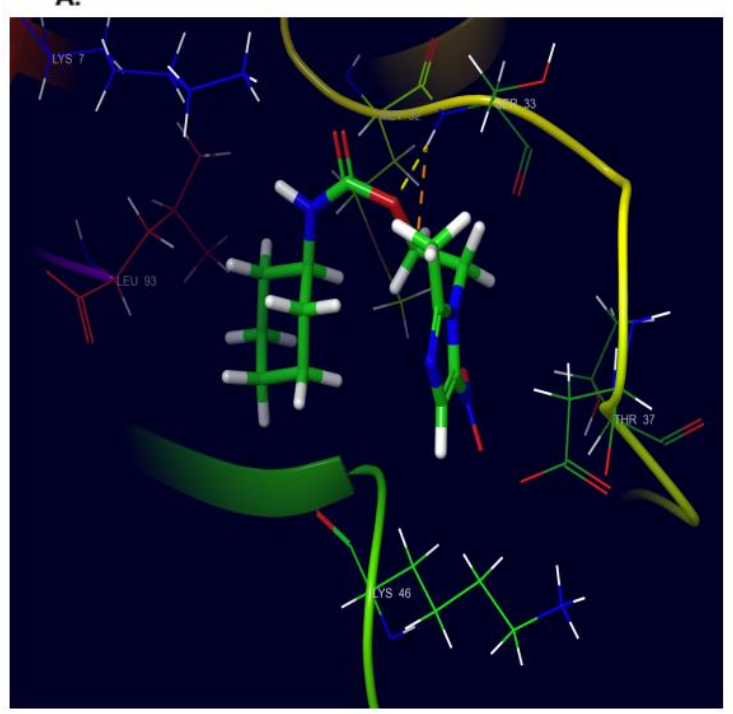

B.

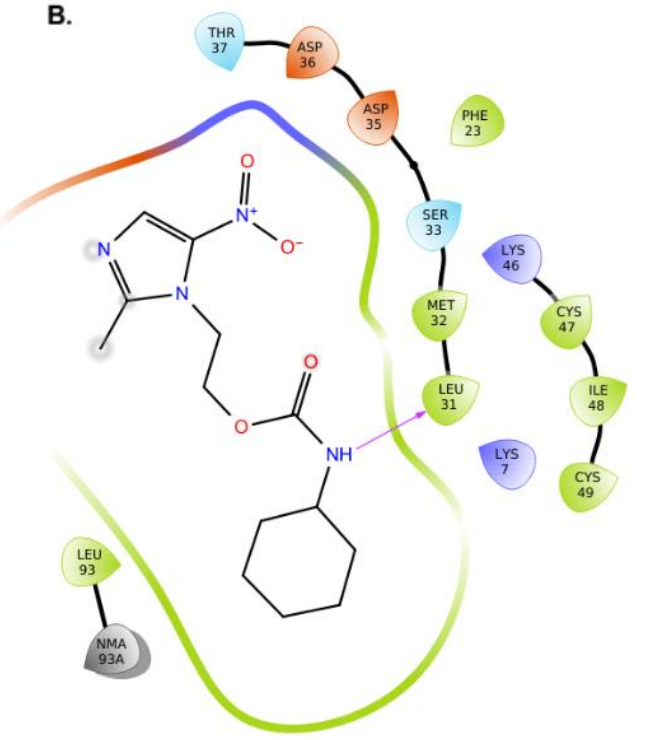

Figure 4. (A) 3D and (B) 2D representations of the binding model of compound 1 in the proposed site for metronidazole in pyruvate-ferredoxin oxidoreductase (PFOR).

A.

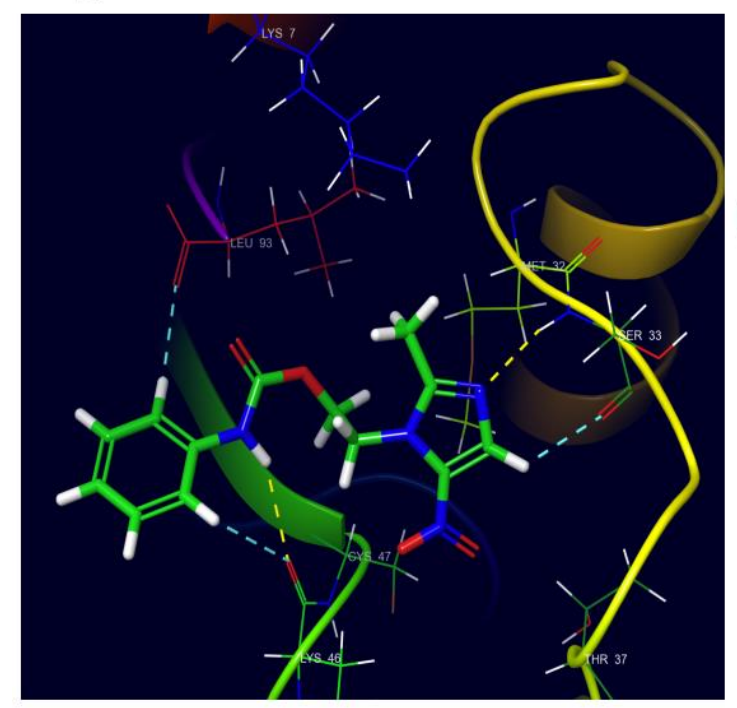

B.

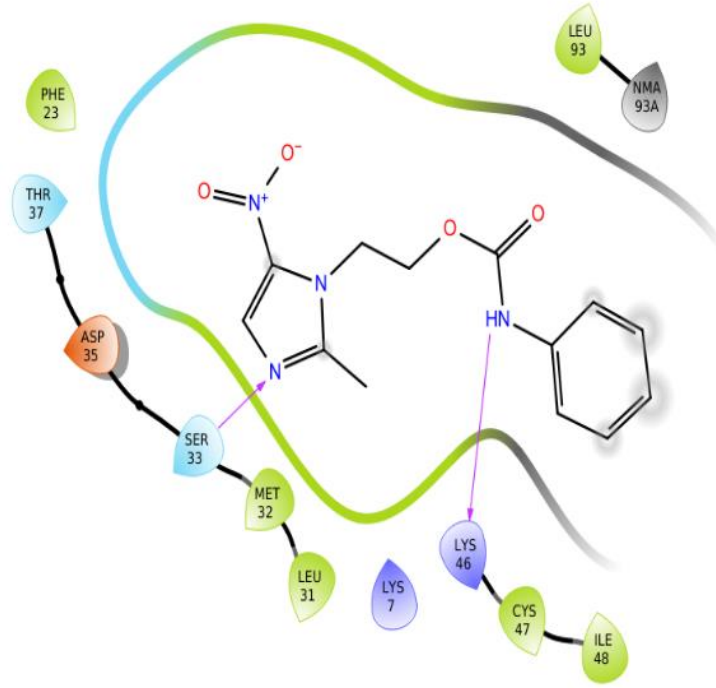

Figure 5. (A) 3D and (B) 2D representations of the binding model of compound 2 in the proposed site for metronidazole in PFOR.

\subsubsection{Dynamics}

Langevin dynamics were simulated to assess the stability of the binding poses obtained with docking and the persistence of residue contacts over time. Langevin dynamics were chosen due to their physics, as its equations introduce dissipation and fluctuation terms, which account for multi-body contributions to the interaction [15]. Thus, Langevin dynamics are suited for accurate description of non-equilibrium and diffusion processes [16]. Langevin dynamics showed that protein-ligand complexes of compounds $\mathbf{1}$ and $\mathbf{2}$ in the colchicine site of $\beta$-tubulin are quite stable (Figures 6 and 7). When residue contacts were examined, we found compound 1 shows different contacts when compared to docking pose (Figure 8). This is in agreement with the higher fluctuations of the 5-nitroimidazole ring, which changed its orientation towards Glu-197 and His-264. This observation further supports the proposed arrangement by Aguayo-Ortíz et al. [10]. During the dynamics simulations, compound 2 maintains H-bond contacts with Ser-238, Gln-245, Leu-246, and Asn-247. On such a short time 
scale, the compounds showed different orientations from a similar starting point. Considering the observed difference in $\mathrm{IC}_{50}$ values, a possible explanation is that both compounds need to move to the nocodazole site; in this case, the higher conformational freedom of the cyclohexane ring could provide a significant advantage. Further testing is require to confirm these observations, starting with longer simulation times to see if a similar behavior is shown for compound 2. Future experimental testing to corroborate the in silico studies should include binding assays of compounds $\mathbf{1}$ and $\mathbf{2}$ with the proposed molecular targets, but these experiments were beyond the focus of this work on in vitro antiparasitic activity.
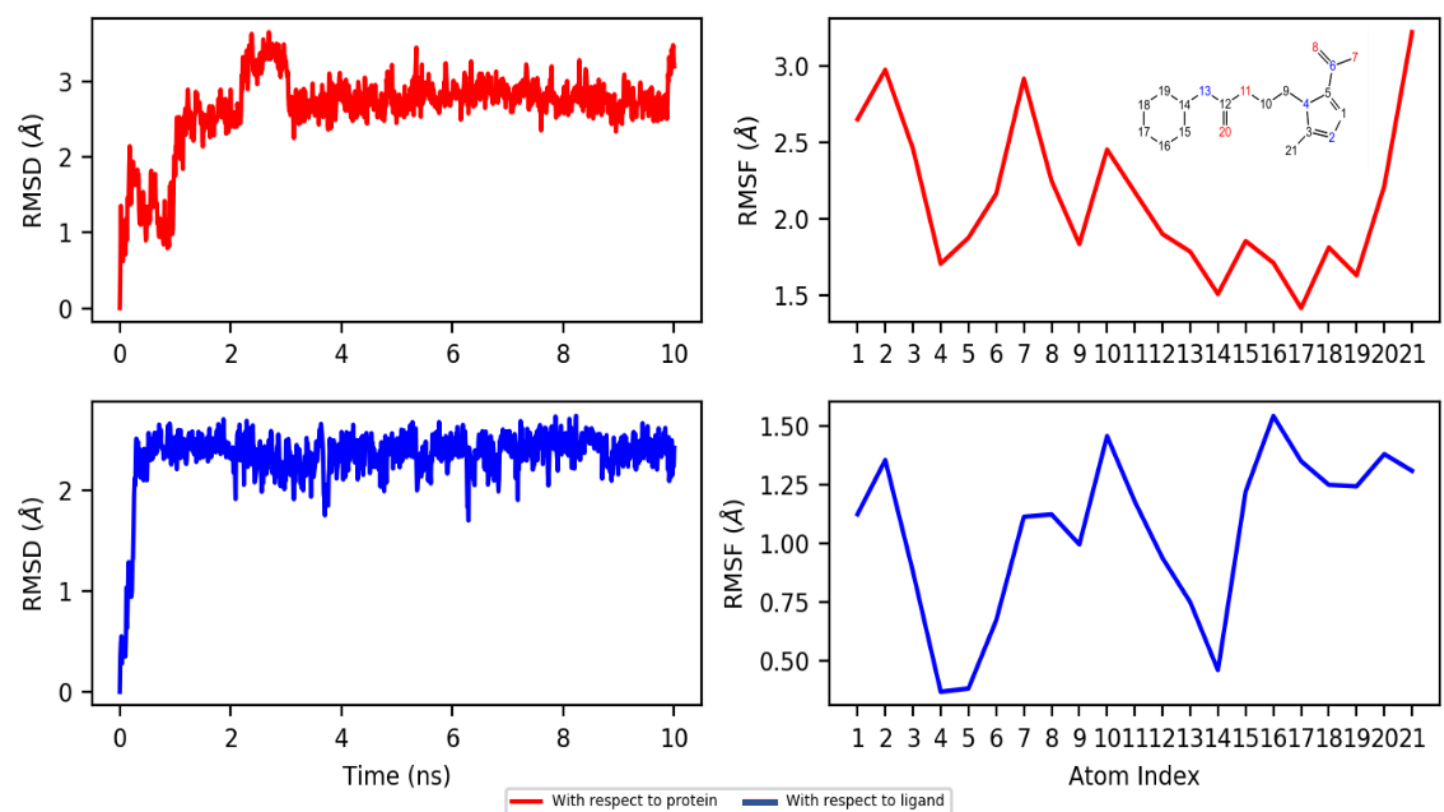

Figure 6. Dynamics of the top pose of compound 1 in the colchicine site of $\beta$-tubulin. Root mean square deviation (RMSD, left) and root mean square fluctuation (RMSF, right) are shown with respect to the protein fit (red) and the initial pose (blue).
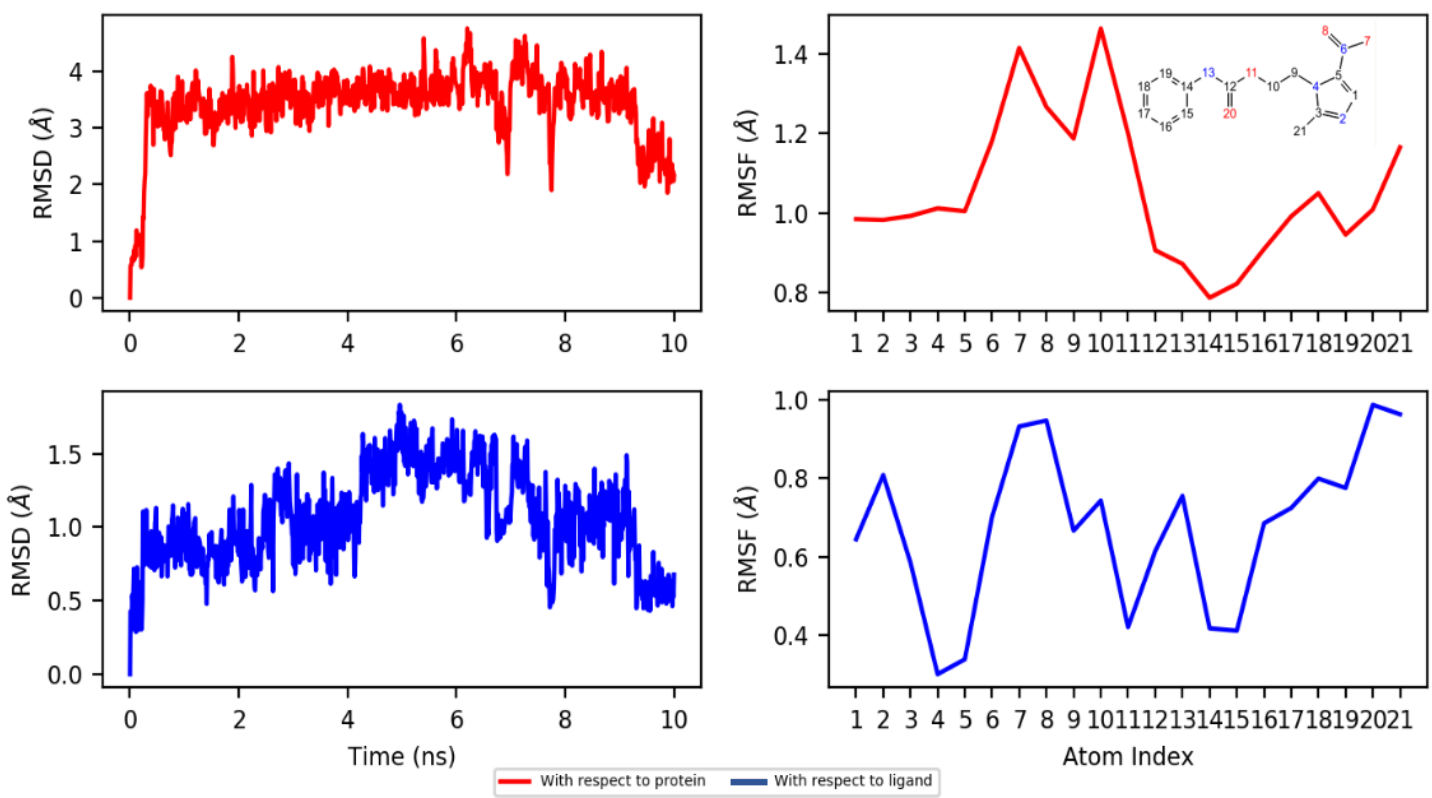

Figure 7. Dynamics of the top pose of compound 2 in the colchicine site of $\beta$-tubulin. RMSD (left) and RMSF (right) with respect to protein fit (red) and the initial pose (blue). 


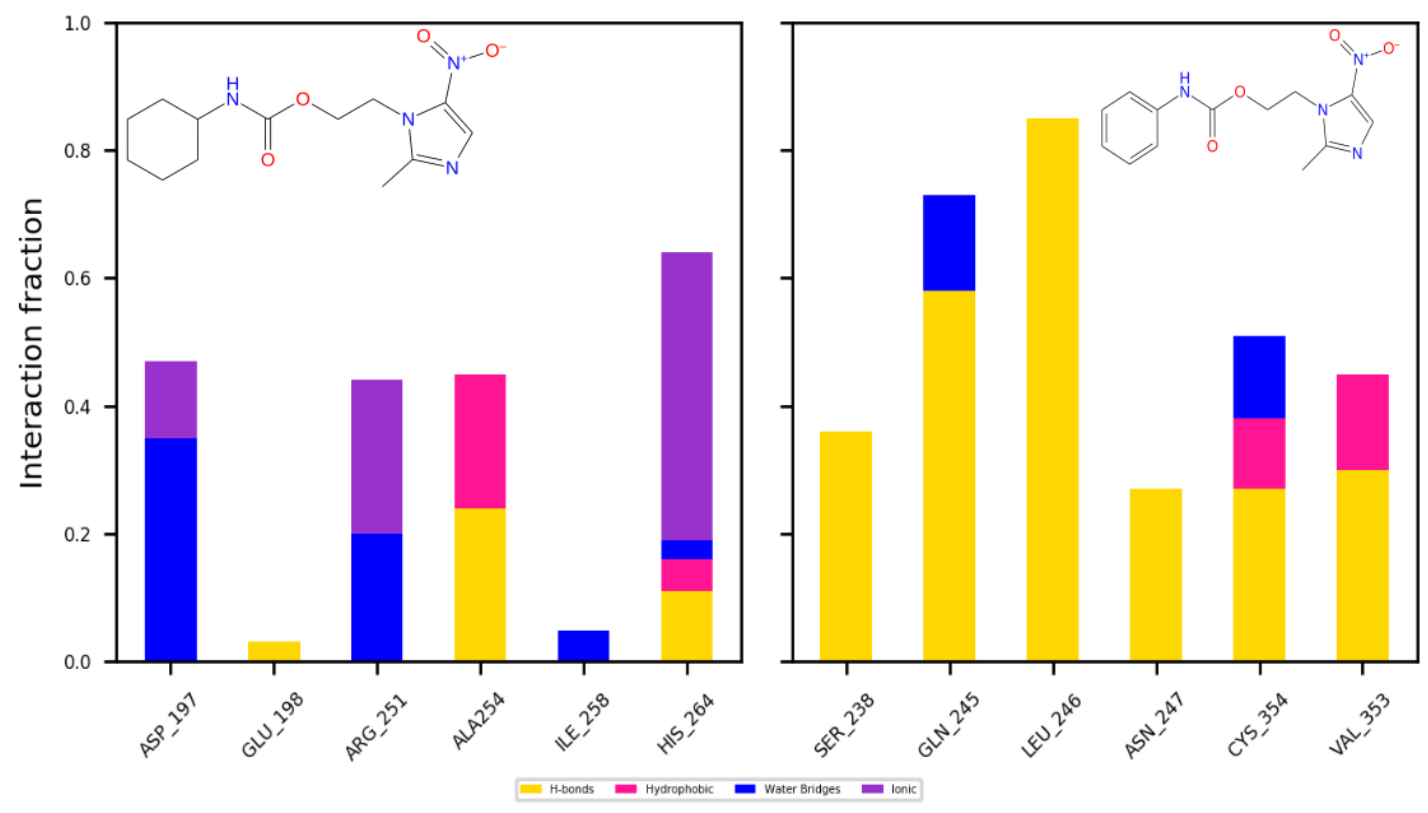

Figure 8. Protein-ligand interactions determined from the molecular dynamics of $\beta$-tubulin/ nitroimidazole complexes: H-bond (yellow), hydrophobic (pink), water bridges (blue), and ionic (violet) interactions.

For binding poses with PFOR, compound 1 showed less movement and fluctuations compared to 2. In docking, $\mathbf{1}$ showed a better fit with PFOR compared to 2 . This result is mainly due to the planarity of the benzene ring, which is the group showing higher fluctuations over the course of the simulations (Figures 9 and 10). The simulations showed that both compounds maintain contact with Ser-33 via a H-bond.
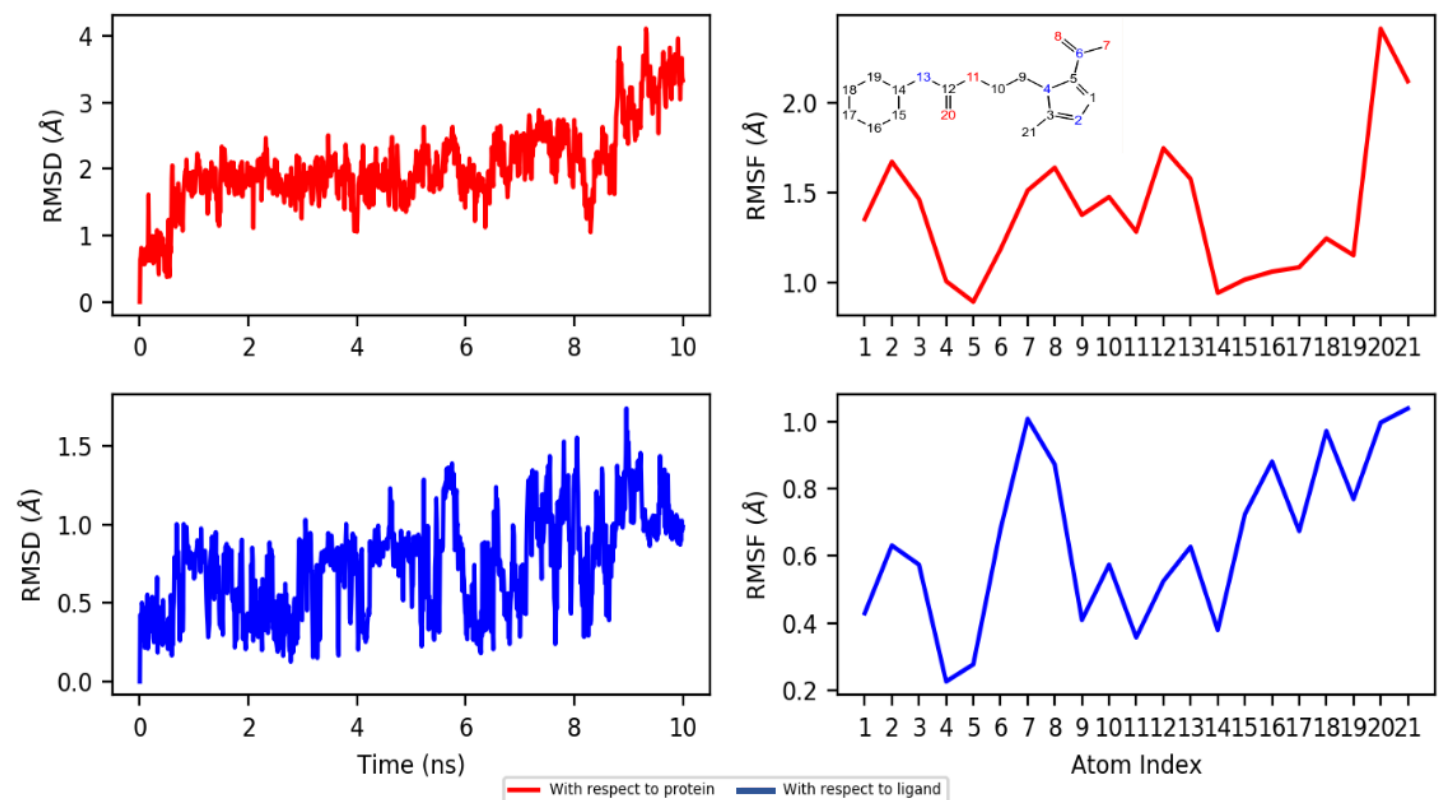

Figure 9. Dynamics of the top pose of compound 1 in the ligand recognition site of PFOR. RMSD (left) and RMSF (right) are shown with respect to protein fit (red) and the initial pose (blue). 

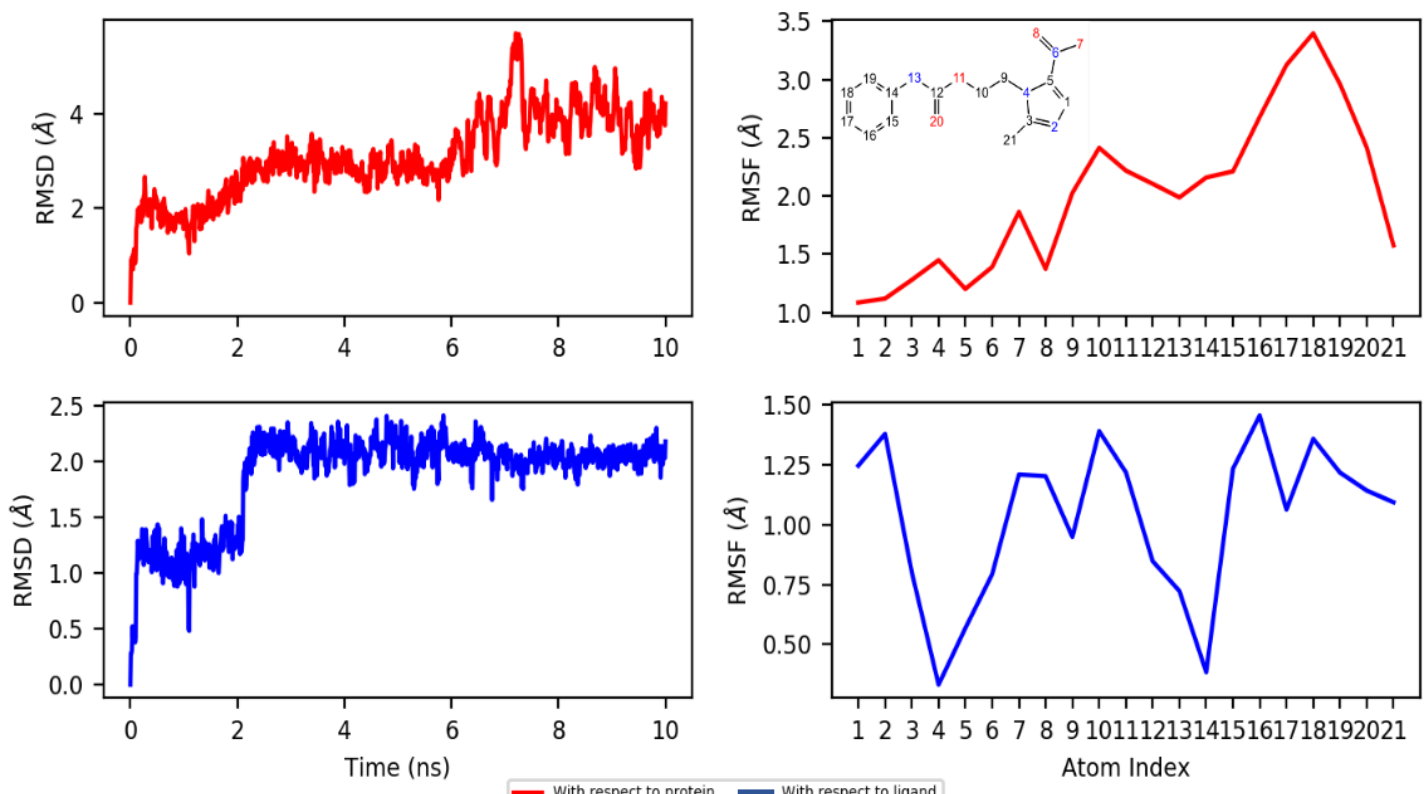

Figure 10. Dynamics of the top pose of compound 2 in the ligand recognition site of PFOR. RMSD (left) and RMSF (right) are shown with respect to protein fit (red) and the initial pose (blue).

The main differences between $\mathbf{1}$ and $\mathbf{2}$ are the conserved contact with Lys-31 in the former and a higher contact rate with Lys-7 and -46 in the latter (Figure 11). Based on these observations, Ser-33 seems to be the main contact for proper orientation with the site; however, this interaction was only observed for $\mathbf{1}$ in a dynamic setting.

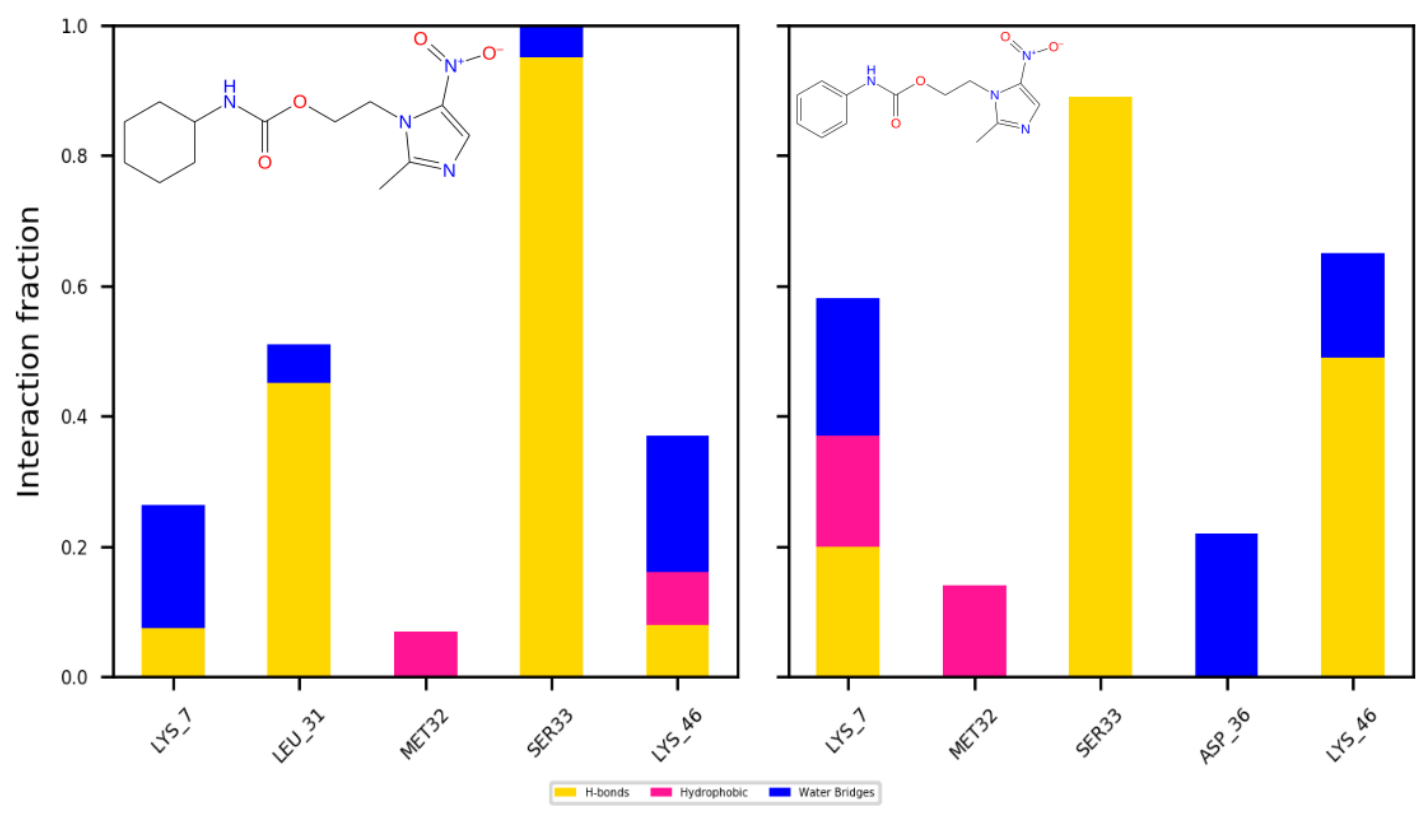

Figure 11. Protein-ligand interactions as obtained from molecular dynamics of PFOR/nitroimidazole complexes: H-bond (yellow), hydrophobic (pink), and water bridges (blue) interactions.

\section{Materials and Methods}

\subsection{Chemistry}

Solvents and reagents were acquired from Sigma-Aldrich (St. Louis, MO, USA). Melting points were obtained using a capillary apparatus from Stanford Research Systems (Sunnyvale, CA, USA). 
All reactions were monitored by thin layer chromatography (TLC) on $0.2 \mathrm{~mm}$ precoated silica gel $60 \mathrm{~F}_{254}$ Merck plates (Kenilworth, NJ, USA). ${ }^{1} \mathrm{H}$ NMR spectra were determined on Varian $600 \mathrm{MHz}$ AR Premium Compact (Varian-Agilent, Santa Clara, CA, USA) and ${ }^{13} \mathrm{C}$ NMR $(150 \mathrm{MHz})$ instrument (Varian-Agilent, Santa Clara, CA, USA). Chemical shifts are reported in ppm in DMSO-d 6 and $\mathrm{CDCl}_{3}$ as deuterated solvents. Mass spectrometry was obtained from a JEOL JMS-700 spectrometer by electronic impact (JEOL, Tokyo, Japan).

\subsection{General Procedure for the Synthesis of Compounds 1-10}

To a solution of metronidazole or secnidazole $(0.0023 \mathrm{~mol})$ in toluene $(5 \mathrm{~mL})$, we dropwise added the suitable isocyanate 13-17 (0.0046 mol, 2 equivalents), $10 \%$ triethylamine, and $\mathrm{NH}_{4} \mathrm{Cl}$ as catalysts at $25^{\circ} \mathrm{C}$. The mixture was stirred at reflux $\left(110^{\circ} \mathrm{C}\right)$ under a nitrogen atmosphere for $7-33 \mathrm{~h}$. The solvent was removed using a high vacuum system, and the residue was suspended in cold water. The solids were recovered by filtration, dried in the hood and recrystallized from suitable solvent.

2-(2-methyl-5-nitro-1H-imidazol-1-yl)ethyl cyclohexylcarbamate (1): $21 \mathrm{~h}$, yield 67\%, recrystallized from ethanol-water, white crystals, $\mathrm{Mp} 103.7^{\circ} \mathrm{C}$ (dec.). ${ }^{1} \mathrm{H}$ NMR $\left(600 \mathrm{MHz}, \mathrm{CDCl}_{3}\right) \delta$ : 1.10-1.31 (m, 4H, H-2', H-6'), 1.57-1.68 (m, 2H, H-4'), 1.68-1.87 (m, 4H, H-3', H-5'), 2.45 (s, 3H, $\left.\mathrm{CH}_{3}\right)$, 3.39-3.41 (m, 1H, H-1'), $4.35\left(\mathrm{t}, 2 \mathrm{H}, \mathrm{N}-\mathrm{CH}_{2}\right), 4.54\left(\mathrm{t}, 2 \mathrm{H}, \mathrm{O}-\mathrm{CH}_{2}\right), 7.93(\mathrm{~s}, 1 \mathrm{H}, \mathrm{H}-4), 9.32(\mathrm{bs}, 1 \mathrm{H}, \mathrm{N}-\mathrm{H})$

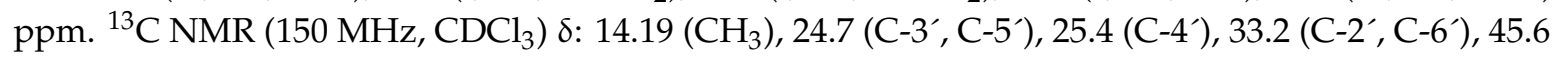
$\left(\mathrm{N}-\mathrm{CH}_{2}\right), 50.04\left(\mathrm{C}-1^{\prime}\right), 62.4\left(\mathrm{O}-\mathrm{CH}_{2}\right), 133.1(\mathrm{C}-4), 138.5(\mathrm{C}-5), 150.8(\mathrm{C}-2), 154.6(\mathrm{C}=\mathrm{O}) \mathrm{ppm} . \mathrm{MS} / \mathrm{EI}: \mathrm{m} / \mathrm{z}$ (\% int. rel). $296.32\left(\mathrm{M}^{+}, 10 \%\right), 225.20$ (M-71, 100\%).

2-(2-methyl-5-nitro- $1 \mathrm{H}$-imidazol-1-yl)ethyl phenylcarbamate (2): $15 \mathrm{~h}$, yield $86 \%$, recrystallized from ethanol-water, white powder Mp $197.7^{\circ} \mathrm{C}$ (dec.). ${ }^{1} \mathrm{H}$ NMR $(600 \mathrm{MHz}, \mathrm{DMSO}-\mathrm{d} 6) \delta: 2.48$ (s, 3H, $\left.\mathrm{CH}_{3}\right), 4.47\left(\mathrm{t}, 2 \mathrm{H}, \mathrm{N}-\mathrm{CH}_{2}\right), 4.63\left(\mathrm{t}, 2 \mathrm{H}, \mathrm{O}-\mathrm{CH}_{2}\right), 7.01\left(\mathrm{t}, 1 \mathrm{H}, \mathrm{H}-4^{\prime}\right), 7.27\left(\mathrm{t}, 2 \mathrm{H}, \mathrm{H}-3^{\prime}, \mathrm{H}-5^{\prime}, J o=7.4 \mathrm{~Hz}\right)$, 7.40 (d, 2H, H-2', H-6', Jo = 7.6 Hz), 8.06 (s, 1H, H-4), 9.66 (bs, $1 \mathrm{H}, \mathrm{N}-\mathrm{H}) \mathrm{ppm} .{ }^{13} \mathrm{C}$ NMR $(150 \mathrm{MHz}$,

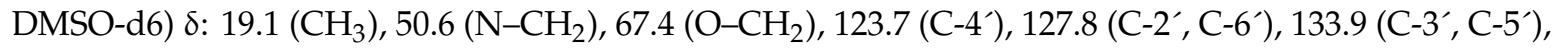
138.3 (C-4), 143.7 (C-5), 143.9 (C-1'), 156.8 (C-2), 158.12 (C=O) ppm. MS/EI: m/z (\% int. rel). 290.27 (M+, $80 \%), 170.05$ (M-120, 100\%).

2-(2-methyl-5-nitro-1H-imidazol-1-yl)ethyl (4-chlorophenyl)carbamate (3): $7 \mathrm{~h}$, yield $65 \%$, recrystallized from ethanol, yellow crystals, Mp 175.0-177.3 ${ }^{\circ} \mathrm{C} ;{ }^{1} \mathrm{H}$ NMR (600 MHz, DMSO-d6) $\delta: 2.45\left(\mathrm{~s}, 3 \mathrm{H}, \mathrm{CH}_{3}\right), 4.45\left(\mathrm{t}, 2 \mathrm{H}, \mathrm{N}-\mathrm{CH}_{2}\right), 4.58\left(\mathrm{t}, 2 \mathrm{H}, \mathrm{O}-\mathrm{CH}_{2}\right), 7.29\left(\mathrm{~d}, 2 \mathrm{H}, \mathrm{H}-2^{\prime}, \mathrm{H}-6^{\prime}, J o=8.9 \mathrm{~Hz}\right)$, 7.39 (d, 2H, H-3', H-5', Jo = 8.9 Hz), 8.02 (s, 1H, H-4), 9.77 (bs, 1H, N-H) ppm. ${ }^{13} \mathrm{C}$ NMR $(150 \mathrm{MHz}$,

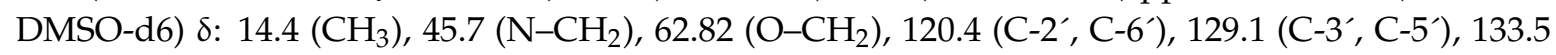
(C-1'), 138.2 (C-4), 138.9 (C-5), 152.1 (C-2), 153.3 (C=O) ppm. MS/EI: $\mathrm{m} / z$ (\% int. rel). $324.71\left(\mathrm{M}^{+,} 100 \%\right)$, $325.16(\mathrm{M}+2,33 \%)$.

2-(2-methyl-5-nitro-1H-imidazol-1-yl)ethyl (4-fluorophenyl)carbamate (4): $9 \mathrm{~h}$, yield 77\%, recrystallized from ethanol-water, yellow crystals, $\mathrm{Mp}$ 168.2-170.6 ${ }^{\circ} \mathrm{C} ;{ }^{1} \mathrm{H}$ NMR $(600 \mathrm{MHz}$, DMSO-d6)

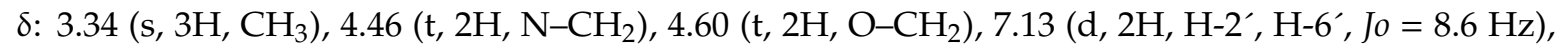
$7.10\left(\mathrm{~d}, 2 \mathrm{H}, \mathrm{H}-3^{\prime}, \mathrm{H}-5^{\prime}, \mathrm{Jo}=8.6 \mathrm{~Hz}\right), 8.02(\mathrm{~s}, 1 \mathrm{H}, \mathrm{H}-4), 9.63(\mathrm{bs}, 1 \mathrm{H}, \mathrm{N}-\mathrm{H}) \mathrm{ppm} .{ }^{13} \mathrm{C}$ NMR $(150 \mathrm{MHz}$, DMSO-d6) 8: $14.4\left(\mathrm{CH}_{3}\right), 45.8\left(\mathrm{~N}-\mathrm{CH}_{2}\right), 62.7\left(\mathrm{O}-\mathrm{CH}_{2}\right), 115.7\left(\mathrm{~d}, \mathrm{C}-3^{\prime}, \mathrm{C}^{-} 5^{\prime},{ }^{2} \mathrm{~J}_{\mathrm{C}-\mathrm{F}}=21 \mathrm{~Hz}\right), 120.6(\mathrm{C}-1)$, 133.5 (C-2', C-6'), 135.4 (C-5), 138.9 (C-4), 152.07 (C-2), $153.5(\mathrm{C}=\mathrm{O}), 158.2\left(\mathrm{~d}, \mathrm{C}^{\prime} 4^{\prime},{ }^{1} \mathrm{~J}_{\mathrm{C}-\mathrm{F}}=237.6 \mathrm{~Hz}\right)$. MS/EI: $m / z$ (\% int. rel). 308.26 (M $\left.\mathrm{M}^{+}, 10 \%\right), 137.13$ (M-171, 100\%).

2-(2-methyl-5-nitro-1H-imidazol-1-yl)ethyl (4-nitrophenyl)carbamate (5): $10 \mathrm{~h}$, yield 87\%, recrystallized from ethanol, yellow crystals, Mp 253.9-256.0 ${ }^{\circ} \mathrm{C} .{ }^{1} \mathrm{H}$ NMR (600 MHz, DMSO-d6) $\delta: 2.48\left(\mathrm{~s}, 3 \mathrm{H}, \mathrm{CH}_{3}\right), 4.50\left(\mathrm{t}, 2 \mathrm{H}, \mathrm{N}-\mathrm{CH}_{2}\right), 4.85\left(\mathrm{t}, 2 \mathrm{H}, \mathrm{O}-\mathrm{CH}_{2}\right), 7.62\left(\mathrm{~d}, 2 \mathrm{H}, \mathrm{H}-2^{\prime}, \mathrm{H}-6^{\prime}\right.$, Jo $\left.=9.8 \mathrm{~Hz}\right)$, 8.14 (s, 1H, H-4), 8.28 (d, 2H, H-3', H-5', Jo = 9.8 Hz), 9.69 (bs, $1 \mathrm{H}, \mathrm{N}-\mathrm{H})$ ppm. ${ }^{13} \mathrm{C} \mathrm{NMR}(150 \mathrm{MHz}$, DMSO-d6) 8: $14.2\left(\mathrm{CH}_{3}\right), 44.5\left(\mathrm{~N}-\mathrm{CH}_{2}\right), 61.9\left(\mathrm{O}-\mathrm{CH}_{2}\right), 117.6$ (C-2', C-6'), $124.6\left(\mathrm{C}-3^{\prime}, \mathrm{C}^{\prime} 5^{\prime}\right), 129.4(\mathrm{C}-4)$,

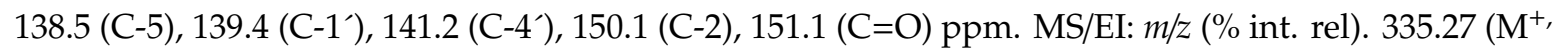
$100 \%), 125.96$ (M-209, 20\%).

1-methyl-2-(2-methyl-5-nitro-1H-imidazol-1-yl)ethyl cyclohexylcarbamate (6): $21 \mathrm{~h}$, yield 51\%, recrystallized from ethanol-water, white crystals, Mp 219.2-222.7 ${ }^{\circ} \mathrm{C} .{ }^{1} \mathrm{H}$ NMR (600 MHz, DMSO-d6) 


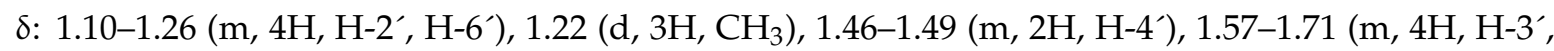
H-5'), 2.42 (s, 3H, $\left.\mathrm{CH}_{3}\right), 4.18-4.22\left(\mathrm{~m}, 1 \mathrm{H}, \mathrm{H}-1^{\prime}\right), 4.48\left(\mathrm{~d}, 2 \mathrm{H}, \mathrm{N}^{\prime} \mathrm{CH}_{2}\right), 5.04-5.07$ (m, 1H, O-CH), 7.93 (s, 1H, H-4), 9.32 (bs, 1H, N-H) ppm. ${ }^{13} \mathrm{C}$ NMR (150 MHz, DMSO-d6) 8: $14.4\left(\mathrm{CH}_{3}\right), 17.9\left(\mathrm{CH}_{3}\right), 25.4$

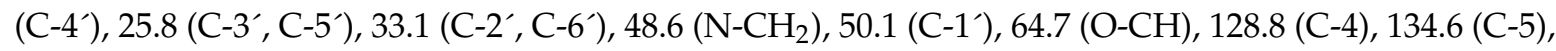
$153.4(\mathrm{C}-2), 155.7(\mathrm{C}=\mathrm{O})$ ppm. MS/EI: $m / z$ (\% int. rel). $310.34\left(\mathrm{M}^{+,} 1 \%\right), 264.13(\mathrm{M}-46,20 \%), 139.11$ (M-171, 100\%).

1-methyl-2-(2-methyl-5-nitro-1H-imidazol-1-yl)ethyl phenylcarbamate (7): $33 \mathrm{~h}$, yield 19\%, recrystallized from ethanol-water, white crystals, Mp 238.9-240.5 ${ }^{\circ} \mathrm{C} .{ }^{1} \mathrm{H}$ NMR (600 MHz, DMSO-d6) $\delta: 1.31\left(\mathrm{~d}, 3 \mathrm{H}, \mathrm{CH}_{3}\right), 2.47\left(\mathrm{~s}, 3 \mathrm{H}, \mathrm{CH}_{3}\right), 4.57\left(\mathrm{~d}, 2 \mathrm{H}, \mathrm{N}-\mathrm{CH}_{2}\right), 5.18-5.20(\mathrm{~m}, 1 \mathrm{H}, \mathrm{O}-\mathrm{CH}), 6.92-695(\mathrm{~m}$, 1H, H-4') , 7.23-7.26 (m, 2H, H-3'-H5'), 7.42 (dd, 2H, H-2', H,6', Jm = 1.14, Jo= 8.64 Hz), 7.99 (s, 1H, $\mathrm{H}-4), 9.52$ (bs, $1 \mathrm{H}, \mathrm{N}-\mathrm{H}) \mathrm{ppm} .{ }^{13} \mathrm{C}$ NMR (150 MHz, DMSO-d6) $\delta: 14.5\left(\mathrm{CH}_{3}\right), 17.9\left(\mathrm{CH}_{3}\right), 46.9\left(\mathrm{~N}-\mathrm{CH}_{2}\right)$, $59.8(\mathrm{O}-\mathrm{CH}), 118.3$ (C-2', C-6') 122.3 (C-4'), 129.2 (C-3'-C-5'), 133.5 (C-4), 138.6 (C-1'), 140.1 (C-5), 152.9 (C-2), 161.1 (C=O) ppm. MS/EI: $m / z$ (\% int. rel). 304.30 (M+20\%), 258.08 (M-46, 30\%), 139.11 (M-165, 100\%).

1-methyl-2-(2-methyl-5-nitro-1H-imidazol-1-yl)ethyl (4-chlorophenyl)carbamate (8): $17 \mathrm{~h}$, yield $91 \%$, recrystallized from acetone, white crystals, Mp $268.1{ }^{\circ} \mathrm{C}$ (dec.). ${ }^{1} \mathrm{H}$ NMR $(600 \mathrm{MHz}$, DMSO-d6) $\delta: 1.03\left(\mathrm{~d}, 3 \mathrm{H}, \mathrm{CH}_{3}\right), 2.05\left(\mathrm{~s}, 3 \mathrm{H}, \mathrm{CH}_{3}\right), 4.33\left(\mathrm{~d}, 2 \mathrm{H}, \mathrm{N}-\mathrm{CH}_{2}\right), 5.85-5.87(\mathrm{~m}, 1 \mathrm{H}, \mathrm{O}-\mathrm{CH})$, $7.29\left(\mathrm{dd}, 2 \mathrm{H}, \mathrm{H}-2^{\prime}-\mathrm{H}^{\prime} 6^{\prime}, \mathrm{Jm}=2.22, \mathrm{Jo}=8.88 \mathrm{~Hz}\right), 7.45\left(\mathrm{dd}, 2 \mathrm{H}, \mathrm{H}-3^{\prime}-\mathrm{H}^{\prime} 5^{\prime}, \mathrm{Jm}=2.22, \mathrm{Jo}^{\prime}=8.94 \mathrm{~Hz}\right), 8.80$ (s, 1H, H-4), 9.52 (bs, 1H, N-H) ppm. ${ }^{13} \mathrm{C}$ NMR (150 MHz, DMSO-d6) $\delta: 14.5\left(\mathrm{CH}_{3}\right), 17.9\left(\mathrm{CH}_{3}\right), 50.4$ $\left(\mathrm{N}-\mathrm{CH}_{2}\right), 69.4(\mathrm{O}-\mathrm{CH}), 120.5\left(\mathrm{C}-2^{\prime}, \mathrm{C}^{\prime} 6^{\prime}\right), 126.8\left(\mathrm{C}-4^{\prime}\right), 129.1$ (C-3'-C-5'), $133.5(\mathrm{C}-4), 138.2\left(\mathrm{C}-1^{\prime}\right), 139.1$ (C-5), 152.1 (C-2), 152.9 (C=O) ppm. MS/EI: $m / z$ (\% int. rel). $338.74\left(\mathrm{M}^{+}, 1 \%\right), 152.01$ (M-186, 100\%).

1-methyl-2-(2-methyl-5-nitro-1H-imidazol-1-yl)ethyl (4-fluorophenyl)carbamate (9): $20 \mathrm{~h}$, yield $65 \%$, recrystallized from ethanol-water, yellow crystals, Mp 162.3-163.5 ${ }^{\circ} \mathrm{C} .{ }^{1} \mathrm{H}$ NMR $(600 \mathrm{MHz}$, DMSO-d6) $\delta: 1.31\left(\mathrm{~d}, 3 \mathrm{H}, \mathrm{CH}_{3}\right), 2.06\left(\mathrm{~s}, 3 \mathrm{H}, \mathrm{CH}_{3}\right), 4.56\left(\mathrm{~d}, 2 \mathrm{H}, \mathrm{N}-\mathrm{CH}_{2}\right), 5.16-5.21(\mathrm{~m}, 1 \mathrm{H}, \mathrm{O}-\mathrm{CH})$, 7.04-7.10 (m,2H, H-3'-H-5'), 7.42 (dd, 2H, H-2'-H-6' Jm = 2.4, Jo = 9.18 Hz), 7.98 (s, 1H, H-4), 9.56 (bs, $1 \mathrm{H}, \mathrm{N}-\mathrm{H}) \mathrm{ppm} .{ }^{13} \mathrm{C}$ NMR $(150 \mathrm{MHz}, \mathrm{DMSO}-\mathrm{d} 6) \delta: 14.5\left(\mathrm{CH}_{3}\right), 17.9\left(\mathrm{CH}_{3}\right), 50.4\left(\mathrm{~N}-\mathrm{CH}_{2}\right), 69.2(\mathrm{O}-\mathrm{CH})$, $115.7\left(\mathrm{~d}, \mathrm{C}-3^{\prime}, \mathrm{C}^{-} 5^{\prime},{ }^{2} J_{\mathrm{C}-\mathrm{F}}=22.5 \mathrm{~Hz}\right), 120.5\left(\mathrm{~d}, \mathrm{C}-2^{\prime}, \mathrm{C}^{-6} 6^{\prime},{ }^{3} J_{\mathrm{C}-\mathrm{F}}=9 \mathrm{~Hz}\right), 133.6(\mathrm{C}-4), 136.4\left(\mathrm{~d}, \mathrm{C}-1^{\prime},{ }^{4} J_{\mathrm{C}-\mathrm{F}}=\right.$ $3 \mathrm{~Hz}), 139.0$ (C-5), $152.1(\mathrm{C}-2), 153.1(\mathrm{C}=\mathrm{O}), 157.8$ (d, C-4', $\left.{ }^{4} \mathrm{~J}_{\mathrm{C}-\mathrm{F}}=237 \mathrm{~Hz}\right) \mathrm{ppm}$. MS/EI: $m / z$ (\% int. rel). $322.29\left(\mathrm{M}^{+}, 20 \%\right), 276.07(\mathrm{M}-46,10 \%)$.

1-methyl-2-(2-methyl-5-nitro-1H-imidazol-1-yl)ethyl (4-nitrophenyl)carbamate (10): $15 \mathrm{~h}$, yield $65 \%$, recrystallized from ethanol, yellow crystals, Mp $235.4{ }^{\circ} \mathrm{C}$ (dec.). ${ }^{1} \mathrm{H}$ NMR $(600 \mathrm{MHz}$, DMSO-d6) $\delta: 1.34\left(\mathrm{~d}, 3 \mathrm{H}, \mathrm{CH}_{3}\right), 2.05\left(\mathrm{~s}, 3 \mathrm{H}, \mathrm{CH}_{3}\right), 4.58\left(\mathrm{~d}, 2 \mathrm{H}, \mathrm{N}-\mathrm{CH}_{2}\right), 5.23-5.26(\mathrm{~m}, 1 \mathrm{H}, \mathrm{O}-\mathrm{CH}), 7.53(\mathrm{dd}, 2 \mathrm{H}$, H-2'-H-6' Jm = 3.06, Jo = 9.3 Hz), 7.98 (s, 1H, H-4), 8.18 (dd, 2H, H-3'-H-5', Jm = 3.1, Jo = 9.3 Hz), 9.62 (bs, $1 \mathrm{H}, \mathrm{N}-\mathrm{H})$ ppm. ${ }^{13} \mathrm{C}$ NMR (150 MHz, DMSO-d6) $\delta: 14.5\left(\mathrm{CH}_{3}\right), 17.8\left(\mathrm{CH}_{3}\right), 50.22\left(\mathrm{~N}-\mathrm{CH}_{2}\right), 7.01$

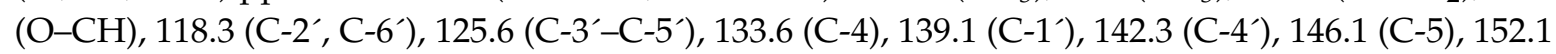
(C-2), 152.7 (C=O) ppm. MS/EI: $m / z$ (\% int. rel). $349.29\left(\mathrm{M}^{+,}\right.$1\%), 137.99 (M-211, 100\%).

\subsection{Biological Assays}

\subsubsection{Giardicidal and Trichomonicidal Assays}

G. intestinalis strain IMSS:0696:1 and T. vaginalis strain GT3 were cultured in TYI-S-33 medium, complemented with $10 \%$ calf serum and bovine bile [12]. In vitro susceptibility assays were executed using $4 \times 10^{4}$ trophozoites of G. intestinalis or T. vaginalis, which were incubated at $37^{\circ} \mathrm{C}$ for $48 \mathrm{~h}$ with cumulative concentrations of carbamates 1-10, metronidazole, and secnidazole, and also incubated alone in culture medium, with DMSO used as the solvent (0.05\%). Subsequently, trophozoites were washed and subcultured for another $48 \mathrm{~h}$ in fresh medium without any drugs. Once this time was reached, trophozoites were counted and the median inhibitory concentration $\left(\mathrm{IC}_{50}\right)$ was calculated. All the experiments were completed in triplicate. 


\subsubsection{Cytotoxicity on VERO Cell Line}

We cultivated $1.5 \times 10^{4}$ VERO cells in a 96-well plate and incubated in DMEM media complemented with $10 \%$ fetal bovine serum, $100 \mu \mathrm{g} / \mathrm{mL}$ streptomycin, and $100 \mathrm{UI} / \mathrm{mL}$ penicillin. The culture was incubated at $37{ }^{\circ} \mathrm{C}$ in a $5 \% \mathrm{CO}_{2}$ atmosphere with $95 \%$ humidity for $48 \mathrm{~h}$. When cells reached $>80 \%$ confluence, the culture media were replaced and the VERO cells were treated with carbamates 1-10, metronidazole, and secnidazole at $1-100 \mu \mathrm{M}$ dissolved in DMSO at a maximum concentration of $0.05 \%$. After $48 \mathrm{~h}$ of incubation, viability of the cells was estimated using the sulforhodamine B method [12]. The concentration of the compounds that killed $50 \%$ of the cells $\left(\mathrm{CC}_{50}\right)$ was calculated by nonlinear fit (GraphPad Prism 4 software). All concentrations were evaluated in triplicate.

\subsection{In Silico Methods}

\subsubsection{Homology Modeling}

The modeling was completed with YASARA (v. 19.12.14) [17], following a protocol detailed elsewhere [18]. Using sequence alignment and analysis [19,20], we identified the $\beta$-tubulin of Bos taurus, Sus scrufa, and Ovis aries as proper templates for the G. duodenallis tubulin model. The model was further refined with a short molecular dynamics simulation (500 ps) with the YASARA2 forcefield, which includes knowledge-based potentials. The simulation was conducted at $298 \mathrm{~K}$ and $1 \mathrm{~atm}$ (NPT ensemble), using an $8 \AA$ cutoff for Van der Waals interactions. Coulombic interactions were computed using the particle mesh Ewald (PME) method [21]. The integration timestep was set at $2 \mathrm{fs}$, with a recording interval of 25 ps. Finally, the quality of the model was assessed by means of Z-score, QMEAN [22], and with the SAVES server (https://servicesn.mbi.ucla.edu/SAVES/), which includes PROCHECK [23], WHATCHECK [24], ERRAT [25], VERIFY 3D [26], and PROVE [27] metrics (see Supplementary Materials).

\subsubsection{Molecular Docking}

The crystal structure of the PFOR (PDB-ID: 1L5P) at $2.2 \AA$ resolution was obtained from the Protein Data Bank (http://www.rcsb.org/pdb) [28]. All docking was calculated with the Molecular Operating Environment (MOE, Chemical Computing Group Inc. Quebec, Canada, http://www.chemcomp.com) version 2019.01 [29]. All water molecules were deleted, and the hydrogen atoms and charges were adjusted with the PFROSST force field from the MOE suite. This forcefield uses AMBER parameters for protein description and MMFF94 for small organic molecules. The 3D structures were built and minimized in MOE; using the same force field as that mentioned above, partial charges were added with MOPAC using the AM1-BCC method [30]. As a validation procedure for the binding sites, metronidazole was blindly docked on both targets (see Supplementary Materials). As a placement function, Alpha Triangle was selected, and the scores were calculated with the GBVI/WSA scoring function, which measures the free energy of binding using forcefield parameters [31] and considers implicit solvation contribution [32]. After the confirmation of binding, the sites were defined around Cys-239 ( $\beta$-tubulin) and Thr-37 (PFOR). The docking was performed considering all residues within a $5.0 \AA$ sphere centered on the defined sites of each target. For each ligand, 10,000 conformations were generated prior to placement. The top 100 placements were refined by scoring function. After molecular docking, the best binding poses were visually inspected. Finally, graphical representations of ligand interactions were created in Maestro (Schrödinger, NY, USA). The top-ranked poses were selected for further analysis with molecular dynamics.

\subsubsection{Molecular Dynamics}

Non-equilibrium Langevin dynamics were used to determine the putative stability of binding modes obtained from docking with Desmond [33].

Using the top poses of the most active compounds as starting point, protein-ligand complexes were prepared in Maestro (19-2), with the System Builder utility. The complexes were buffered in 
a truncated octahedron box with a $14.0 \AA$ solvent shell around the protein, the system was neutralized, and $\mathrm{NaCl}$ was added to obtain a $0.15 \mathrm{M}$ concentration. The system was parameterized with the OPLS 2005 force field. Each system was minimized in three steps, using Brownian dynamics under NVT ensemble at $10 \mathrm{~K}$ with a small time-step to avoid numerical errors [34], first with a $1000 \mathrm{kcal} / \mathrm{mol} / \AA$ restraint on solute heavy atoms for $250 \mathrm{ps}$, followed by another 250 ps of Brownian dynamics in similar conditions with a $10 \mathrm{kcal} / \mathrm{mol} / \AA$ restraint on the protein backbone. Finally, the simulation was conducted for 500 ps without restraints. Then the complexes were further relaxed by heating slowly from 10 to $300 \mathrm{~K}$ in the NVT ensemble for 500 ps using the Berendsen thermostat and a 2 fs timestep. This was followed by a 1000 ps relaxation in NPT (1 atm) ensemble using a Langevin thermostat and barostat (with a relaxation times of 0.02 and 1.0 ps, respectively). Production runs lasted $10 \mathrm{~ns}$, which were repeated 10 times using different random seeds. Trajectories were analyzed with the simulation interaction diagram utility. Ligand RMSD, RMSF, and residue contacts from each run were compared to obtain the average behavior and the relative stability of the pose [35].

\section{Conclusions}

We reported the one-step preparation of 10 carbamate derivatives of metronidazole and secnidazole in modest yields, which showed strong nanomolar and micromolar antiprotozoal activity against two amitochondriate parasites, Giardia duodenalis and Trichomonas vaginalis, with no observable cytotoxic effects in mammalian VERO cells. The giardicidal effect of carbamates 1-10 was improved compared to the two first-line commercial drugs: metronidazole and secnidazole. All compounds showed trichomonicidal effects greater than secnidazole. The antiprotozoal effect could be related to the higher lipophilicity of the 10 compounds, because they could penetrate the protozoal membrane more effectively. The most active compounds were $\mathbf{1}$ and $\mathbf{2}$, which are metronidazole cyclohexylcarbamate and phenylcarbamate, respectively. The plausible modes of action of compounds $\mathbf{1}$ and $\mathbf{2}$ involve inhibition of PFOR and $\beta$-tubulin as suggested by docking and molecular dynamics.

Supplementary Materials: The following are available online at http://www.mdpi.com/1420-3049/25/4/793/s1, Figure S1. Multiple sequence alignment of $\beta$-tubulin from different organisms used in this study, Figure S2. Global quality measures of the homology model constructed; Figure S3. Additional quality assessment of the homology model. (A) Main Ramachandran plot. (B) 3D structure of homology model colored by quality. (C) QMEAN4 normalized score. (D) Local quality per-residue; Figure S4. Model quality obtained from SAVES server. (A) Residue distribution. (B) Verify 3D. (C) ERRAT; Figure S5. Docking pose of metronidazole in PFOR. (A) 3D and surface representation. (B) 2D residue contacts; Figure S6. Docking pose of metronidazole in $\beta$-tubulin. (A) 3D and surface representation. (B) 2D residue contacts; Table S1. Template scoring as obtained by PSI-BLAST and YASARA; Table S2. Docking scores of the top five poses of metronidazole and the most active compounds in the proposed binding site of PFOR; Table S3. Docking scores of the top five poses of metronidazole and the most active compounds in the proposed binding site of $\beta$-tubulin.

Author Contributions: G.R.-G. and N.A.H.-M.: performed the chemical synthesis of all compounds, did the acquisition of antiparasitic in vitro data, and analyzed the chemical and biological results. B.C.-L. and S.E.-S.: interpreted the data for SAR analysis, contributed with reagents and analysis tools, drafted some parts of the manuscript and did a critical revision. F.D.P.-M., and J.L.M.-F.: obtained the homology model for $\beta$-Tubulin of G. duodenalis; performed and analyzed the molecular docking and dynamics of PFOR and $\beta$-Tubulin complexes. E.H.-N.: performed and interpreted the spectroscopic analysis using nuclear magnetic resonance. R.M.-P. and J.B.C.-D.: Carried out and interpreted the antiprotozoal and cytotoxic assays. G.N.-V.: Developed the concept, designed the compounds, funding Acquisition, prepared and wrote the manuscript. All authors have read and agreed to the published version of the manuscript.

Funding: This research and the APC were funded by the Consejo Nacional de Ciencia y Tecnología (CONACyT), grant No. 253814 (Ciencia Básica 2015) given to G. Navarrete-Vazquez.

Acknowledgments: The work was funded by the Consejo Nacional de Ciencia y Tecnología (CONACyT), grant No. 253814 (Ciencia Básica 2015) given to G. Navarrete-Vazquez. N. A. Hernandez-Martinez received a CONACYT fellowship (No. 28327) to complete her Bachelor in Pharmacy studies. We thank NUATEI Program (IIB-UNAM) to provide funding to purchase YASARA software. We are in debt to Rodrigo Ortiz-Aguayo for providing us the first $\beta$-tubulin homology model. F.D. Prieto-Martínez is grateful to CONACYT for the PhD. scholarship granted (No. 660465/576637). The authors are also grateful to Diego Prada-Garcia and Liliana M. Moreno-Vargas, as their suggestions were highly valuable. This article is dedicated to Gabriel Navarrete-Alemán in his 78th birthday.

Conflicts of Interest: The authors declare no conflict of interest. 


\section{References}

1. Ortega-Pierres, M.G.; Argüello-García, R. Giardia duodenalis: Role of secreted molecules as virulent factors in the cytotoxic effect on epithelial cells. Adv. Parasitol. 2019, 106, 129-169. [CrossRef]

2. Bala, V.; Chhonker, Y.S. Recent developments in anti-Trichomonas research: An update review. Eur. J. Med. Chem. 2018, 143, 232-243. [CrossRef] [PubMed]

3. Leitsch, D.; Schlosser, S.; Burgess, A.; Duchêne, M. Nitroimidazole drugs vary in their mode of action in the human parasite Giardia lamblia. Int. J. Parasitol. Drugs Drug Resist. 2012, 2, 166-170. [CrossRef] [PubMed]

4. Dingsdag, S.A.; Hunter, N. Metronidazole: An update on metabolism, structure-cytotoxicity and resistance mechanisms. J. Antimicrob. Chemother. 2018, 73, 265-279. [CrossRef] [PubMed]

5. Müller, J.; Braga, S.; Heller, M.; Müller, N. Resistance formation to nitro drugs in Giardia lamblia: No common markers identified by comparative proteomics. Int. J. Parasitol. Drugs Drug Resist. 2019, 9, 112-119. [CrossRef] [PubMed]

6. Hernández-Núñez, E.; Tlahuext, H.; Moo-Puc, R.; Torres-Gómez, H.; Reyes-Martínez, R.; Cedillo-Rivera, R.; Nava-Zuazo, C.; Navarrete-Vazquez, G. Synthesis and in vitro trichomonicidal, giardicidal and amebicidal activity of N-acetamide(sulfonamide)-2-methyl-4-nitro-1H-imidazoles. Eur. J. Med. Chem. 2009, 44, 2975-2984. [CrossRef]

7. Leitsch, D.; Burgess, A.G.; Dunn, L.A.; Krauer, K.G.; Tan, K.; Duchne, M.; Upcroft, P.; Eckmann, L.; Upcroft, J.A. Pyruvate: Ferredoxin oxidoreductase and thioredoxin reductase are involved in 5-nitroimidazole activation while flavin metabolism is linked to 5-nitroimidazole resistance in Giardia lamblia. J. Antimicrob. Chemother. 2011, 66, 1756-1765. [CrossRef]

8. Hernández-Ochoa, B.; Navarrete-Vázquez, G.; Nava-Zuazo, C.; Castillo-Villanueva, A.; Méndez, S.T.; Torres-Arroyo, A.; Gómez-Manzo, S.; Marcial-Quino, J.; Ponce-Macotela, M.; Rufino-González, Y.; et al. Novel giardicidal compounds bearing proton pump inhibitor scaffold proceeding through triosephosphate isomerase inactivation. Sci. Rep. 2017, 7, 1-14. [CrossRef]

9. Hernández-Núñez, E.; Tlahuext, H.; Moo-Puc, R.; Moreno, D.; González-Díaz, M.O.; Vázquez, G.N. Design, synthesis and biological evaluation of 2-(2-amino-5(6)-nitro-1H-benzimidazol-1-yl)-narylacetamides as antiprotozoal agents. Molecules 2017, 22, 579. [CrossRef]

10. Aguayo-Ortiz, R.; Méndez-Lucio, O.; Romo-Mancillas, A.; Castillo, R.; Yépez-Mulia, L.; Medina-Franco, J.L.; Hernández-Campos, A. Molecular basis for benzimidazole resistance from a novel $\beta$-tubulin binding site model. J. Mol. Graph. Model. 2013, 45, 26-37. [CrossRef]

11. Valladares-Méndez, A.; García-Flores, M.; Navarrete-Vázquez, G.; Orozco-Castellanos, L.M.; Hernandez-Nuñez, E.; Rivera-Leyva, J.C. Physicochemical characterization of two new Nitazoxanide analogs with antiparasitic activity. Med. Chem. Res. 2017, 26, 9-18. [CrossRef]

12. Colín-Lozano, B.; León-Rivera, I.; Chan-Bacab, M.J.; Ortega-Morales, B.O.; Moo-Puc, R.; López-Guerrero, V.; Hernández-Núñez, E.; Argüello-Garcia, R.; Scior, T.; Barbosa-Cabrera, E.; et al. Synthesis, in vitro and in vivo giardicidal activity of nitrothiazole-NSAID chimeras displaying broad antiprotozoal spectrum. Bioorg. Med. Chem. Lett. 2017, 27, 3490-3494. [CrossRef]

13. Naaz, F.; Haider, M.R.; Shafi, S.; Yar, M.S. Anti-tubulin agents of natural origin: Targeting taxol, vinca, and colchicine binding domains. Eur. J. Med. Chem. 2019, 171, 310-331. [CrossRef]

14. Weksberg, T.E.; Lynch, G.C.; Krause, K.L.; Pettitt, B.M. Molecular dynamics simulations of Trichomonas vaginalis ferredoxin show a loop-cap transition. Biophys. J. 2007, 92, 3337-3345. [CrossRef] [PubMed]

15. Lü, J.T.; Hu, B.Z.; Hedegård, P.; Brandbyge, M. Semi-classical generalized Langevin equation for equilibrium and nonequilibrium molecular dynamics simulation. Prog. Surf. Sci. 2019, 94, 21-40. [CrossRef]

16. Chen, J.C.; Kim, A.S. Brownian dynamics, molecular dynamics, and monte carlo modeling of colloidal systems. Adv. Colloid Interface Sci. 2004, 112, 159-173. [CrossRef]

17. Krieger, E.; Vriend, G. YASARA View-molecular graphics for all devices-from smartphones to workstations. Bioinformatics 2014, 30, 2981-2982. [CrossRef]

18. Krieger, E.; Joo, K.; Lee, J.; Lee, J.; Raman, S.; Thompson, J.; Tyka, M.; Baker, D.; Karplus, K. Improving physical realism, stereochemistry, and side-chain accuracy in homology modeling: Four approaches that performed well in CASP8. Proteins Struct. Funct. Bioinforma. 2009, 77, 114-122. [CrossRef] 
19. Altschul, S.F.; Madden, T.L.; Schäffer, A.A.; Zhang, J.; Zhang, Z.; Miller, W.; Lipman, D.J. Gapped BLAST and PSI-BLAST: A new generation of protein database search programs. Nucleic Acids Res. 1997, 25, 3389-3402. [CrossRef]

20. Qiu, J.; Elber, R. SSALN: An alignment algorithm using structure-dependent substitution matrices and gap penalties learned from structurally aligned protein pairs. Proteins Struct. Funct. Genet. 2006, 62, 881-891. [CrossRef]

21. Essmann, U.; Perera, L.; Berkowitz, M.L.; Darden, T.; Lee, H.; Pedersen, L.G. A smooth particle mesh Ewald method. J. Chem. Phys. 1995, 103, 8577-8593. [CrossRef]

22. Benkert, P.; Tosatto, S.C.E.; Schomburg, D. QMEAN: A comprehensive scoring function for model quality assessment. Proteins Struct. Funct. Bioinforma. 2008, 71, 261-277. [CrossRef] [PubMed]

23. Morris, A.L.; MacArthur, M.W.; Hutchinson, E.G.; Thornton, J.M. Stereochemical quality of protein structure coordinates. Proteins Struct. Funct. Bioinforma. 1992, 12, 345-364. [CrossRef] [PubMed]

24. Hooft, R.W.W.; Vriend, G.; Sander, C.; Abola, E.E. Errors in protein structures [3]. Nature 1996, $381,272$. [CrossRef] [PubMed]

25. Colovos, C.; Yeates, T.O. Verification of protein structures: Patterns of nonbonded atomic interactions. Protein Sci. 1993, 2, 1511-1519. [CrossRef]

26. Lüthy, R.; Bowie, J.U.; Eisenberg, D. Assessment of protein models with three-dimensional profiles. Nature 1992, 356, 83-85. [CrossRef]

27. Pontius, J.; Richelle, J.; Wodak, S.J. Deviations from standard atomic volumes as a quality measure for protein crystal structures. J. Mol. Biol. 1996, 264, 121-136. [CrossRef]

28. Berman, H.M.; Westbrook, J.; Feng, Z.; Gilliland, G.; Bhat, T.N.; Weissig, H.; Shindyalov, I.N.; Bourne, P.E. The protein data bank. Nucleic Acids Res. 2000, 28, 235-242. [CrossRef]

29. Molecular Operating Environment (MOE), 2019.012019.

30. Jakalian, A.; Jack, D.B.; Bayly, C.I. Fast, efficient generation of high-quality atomic charges. AM1-BCC model: II. Parameterization and validation. J. Comput. Chem. 2002, 23, 1623-1641. [CrossRef]

31. Naïm, M.; Bhat, S.; Rankin, K.N.; Dennis, S.; Chowdhury, S.F.; Siddiqi, I.; Drabik, P.; Sulea, T.; Bayly, C.I.; Jakalian, A.; et al. Solvated Interaction Energy (SIE) for scoring protein-ligand binding affinities. 1. Exploring the parameter space. J. Chem. Inf. Model. 2007, 47, 122-133. [CrossRef]

32. Labute, P. The generalized Born/volume integral implicit solvent model: Estimation of the free energy of hydration using London dispersion instead of atomic surface area. J. Comput. Chem. 2008, 29, 1693-1698. [CrossRef] [PubMed]

33. Bowers, K.; Chow, E.; Xu, H.; Dror, R.; Eastwood, M.; Gregersen, B.; Klepeis, J.; Kolossvary, I.; Moraes, M.; Sacerdoti, F.; et al. Scalable Algorithms for Molecular Dynamics Simulations on Commodity Clusters. In ACM/IEEE SC 2006 Conference (SC'06), Tampa, FL, USA, 11-17 November 2006; Association for Computing Machinery: New York, NY, USA, 2006.

34. Özen, A.; Sherman, W.; Schiffer, C.A. Improving the resistance profile of hepatitis C NS3/4A inhibitors: Dynamic substrate envelope guided design. J. Chem. Theory Comput. 2013, 9, 5693-5705. [CrossRef] [PubMed]

35. Cob-Calan, N.N.; Chi-Uluac, L.A.; Ortiz-Chi, F.; Cerqueda-García, D.; Navarrete-Vázquez, G.; Ruiz-Sánchez, E.; Hernández-Núñez, E. Molecular Docking and Dynamics Simulation of Protein $\beta$-Tubulin and Antifungal Cyclic Lipopeptides. Molecules. 2019, 24, 3387. [CrossRef] [PubMed]

Sample Availability: Samples of the compounds are available from the authors. 